NBSIR 81-2307

\title{
Dependence of Model Waste Solid Transport Characteristics in Drainage Systems on Solid Geometry, Mass and Pipe System Parameters
}

Dr. J. A. Swaffield

National Engineering Laboratory Center for Building Technology U.S. Department of Commerce National Bureau of Standards Washington, DC 20234

and

Drainage Research Group

Department of Building Technology Brunel University

Uxbridge

U.K.

July 1981
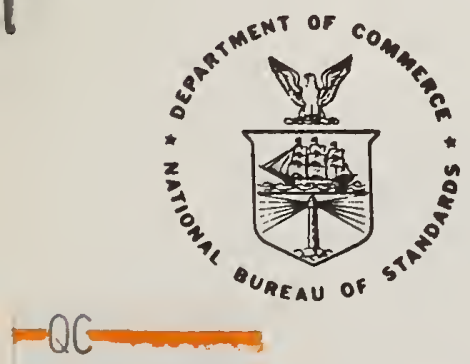



\section{DEPENDENCE OF MODEL WASTE SOLID}

TRANSPORT CHARACTERISTICS IN

DRAINAGE SYSTEMS ON SOLID

GEOMETRY, MASS AND PIPE SYSTEM

PARAMETERS

Dr. J. A. Swaffield

National Engineering Laboratory

Center for Building Technology

U.S. Department of Commerce

National Bureau of Standards

Washington, DC 20234

and

Drainage Research Group

Department of Building Technology

Brunel University

Uxbridge

U.K.

July 1981

U.S. DEPARTMENT OF COMMERCE, Malcolm Baldrige, Secretary NATIONAL BUREAU OF STANDARDS, Ernest Ambler, Director 


\section{ABSTRACT}

Test results are presented for the transport characteristics of an extensive range of geometrically similar model solids in a $100 \mathrm{~mm}$ diameter UPVC drain pipe. Model solids were based on commercially available sanitary towels (napkins) discharged into the pipe system via a series of U.K. standard water closet types.

Following a data fit analysis, relationships are presented linking solid transport characteristics to solid, pipe and water closet (w.c.) parameters.

These relationships, linked to observation of installed hospital drainage systems in the U.K., will allow laboratory test methods to be utilized in predicting the effect of design changes on system performance. 
This report is one of a group documenting National Bureau of Standards (NBS) research and analysis efforts in developing water conservation test methods, analysis, economics, and strategies for implementation and acceptance. This work is sponsored by the Department of Housing and Urban Development/Office of Policy Development and Research, Division of Energy Building Technology and Standards, under HUD Interagency Agreement H48-78.

The report was prepared by Dr. J. A. Swaffield, guest research worker at NBS-Stevens Institute of Technology from Brunel University, U.K.

The test results included in this report were compiled from published work from the Drainage Research Group, Department of Building Technology, Brunel University, U.K.

The test programs were funded by the U.K. Department of Health, the U.K. Association of Sanitary Protection Manufacturers and Brunel University. 
$\underline{\text { Page }}$

ABSTRACT $\ldots \ldots \ldots \ldots \ldots \ldots \ldots \ldots \ldots \ldots \ldots \ldots \ldots \ldots \ldots \ldots \ldots \ldots \ldots \ldots \ldots \ldots \ldots \ldots \ldots \ldots \ldots$

PREFACE $\ldots \ldots \ldots \ldots \ldots \ldots \ldots \ldots \ldots \ldots \ldots \ldots \ldots \ldots \ldots \ldots \ldots \ldots \ldots \ldots \ldots \ldots \ldots \ldots \ldots \ldots$ iv

NOTATION $\ldots \ldots \ldots \ldots \ldots \ldots \ldots \ldots \ldots \ldots \ldots \ldots \ldots \ldots \ldots \ldots \ldots \ldots \ldots \ldots \ldots \ldots \ldots \ldots \ldots \ldots \ldots \ldots$

1. INTRODUCTION $\ldots \ldots \ldots \ldots \ldots \ldots \ldots \ldots \ldots \ldots \ldots \ldots \ldots \ldots \ldots \ldots \ldots \ldots \ldots \ldots \ldots \ldots \ldots \ldots . \ldots . \ldots \ldots$

2. BACKGROUND TO LABORATORY TEST PROGRAM ..................... 2

3. ANALYSIS OF THE VARIABLES GOVERNING SOLID TRANSPORT ........... 4

4. EXPERIMENTAL AND MEASUREMENT TECHNIQUES .................... 6

5. PRESENTATION OF RESULTS $\ldots \ldots \ldots \ldots \ldots \ldots \ldots \ldots \ldots \ldots \ldots \ldots \ldots \ldots \ldots \ldots \ldots \ldots \ldots$. 7

6. DISCUSSION OF RESULTS $\ldots \ldots \ldots \ldots \ldots \ldots \ldots \ldots \ldots \ldots \ldots \ldots \ldots \ldots \ldots \ldots \ldots \ldots \ldots . \ldots$

7. CONCLUSIONS $\ldots \ldots \ldots \ldots \ldots \ldots \ldots \ldots \ldots \ldots \ldots \ldots \ldots \ldots \ldots \ldots \ldots \ldots \ldots \ldots \ldots \ldots \ldots \ldots$

8. REFERENCES ........................................ 12

Appendix 1. Reprint of Reference 5, Flushability Criterla Development for Sanitary Towels, Diapers, and Tampons .............. 18 
Table 1. Summary of Solid Geometry and Mass Measurements Together With System Parameters and Test Results

\section{List of Figures}

Page

Figure 1. Dependance of solid velocity on $\sqrt{(\mathrm{L} / \mathrm{G})}$

Figure 2. Relationship between extrapolated solid velocity at pipe

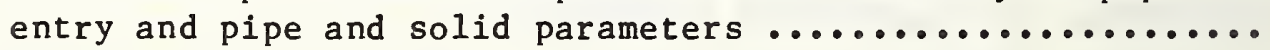

Figure 3. Relationship between solid deceleration with respect to pipe distance traversed and pipe and solid parameters

Figure 4. Predicted solid deposition position based on zero velocity .. 


\section{NOTATION}

$C_{1} \quad$ Extrapolated solid velocity at pipe entry

$\mathrm{C}_{2}$ Solid deceleration with respect to distance

D Pipe diameter

F Total flush volume available

$F_{B} \quad$ Volume discharged behind solid

G Pipe slope

g Accleration due to gravity

$\mathrm{K}_{1} \quad$ Non dimensional solid velocity term at pipe entry

$\mathrm{K}_{2} \quad$ Non dimensional solid deceleration with respect to $\mathrm{L} / \mathrm{D}$

$\mathrm{K}$ Constant in calibration equation

L Pipe length traversed from entry

\& Solid length

$\mathrm{m}_{\mathrm{s}} \quad$ Solid mass (saturated)

$q$ Index in calibration equation

t Solid thickness

V* Non dimensional solid velocity term

v Solid velocity at point $L$

w Solid width

x Characteristic lengths

y Characteristic lengths

$\rho_{\mathrm{w}} \quad$ Water density

UPVC Unplasticized polyvinyl chloride (pipe material) 



\section{INTRODUCTION}

Little use has been made in the past of laboratory based studies to model the waste solid transport characteristics of building drainage systems. This has been due to a lack of understanding of the transport mechanisms involved and the difficulty of producing a suitable model solid for laboratory usage. The test solids utilized for water closet (w.c.) evaluation and type acceptance tests cannot be used to model system transport. The solids commonly used, for example, the European $50 \times 20 \mathrm{~mm}$ diameter ball test, the British single $43 \mathrm{~mm}$ diameter ball test and the Dutch sponge tests, have been designed to reproduce w.c. discharge criteria and would not be representative of system transport. Early transport tests by the Japanese utilizing PVC sponge solids were subject to problems arising from the specific gravity variations of the models that appeared to be dependent on the solid soaking time prior to usage.

A number of criteria need to be satisfied if a laboratory test solid is to be successful in modeling system transport mechanisms:

1. The solid must be cheap and available in bulk to repeatable dimensions and mass. Reusable solids are discounted on the grounds that water soaking time may become an important factor, as may deterioration of the model surface, although impermeable solids with sealed voids could be reused.

2. A sufficient range of geometrically similar solids meeting criterion 1 above should be available if the full range of system loading is to be represented in the laboratory.

3. The solid must be acceptable in the laboratory environment.

4. The transport characteristics of each solid must be documented in terms of its geometry and mass, or be capable of being interpolated from tests on similar solids.

5. The transport characteristics of installed systems should have been monitored to present a range of typical waste transport characteristics. The range of system loading would then be modeled by choosing the appropriate model solids from the documented transport characteristics mentioned in criterion 4 above.

If these points can be met then laboratory tests may be utilized to assess the effect of design changes on the performance of the system. Such modifications as reduced water usage or reductions in pipe slope or diameter could be evaluated. Similarly, the effect of introducing new w.c. designs having lower water usage could be evaluated.

This brief report summarizes a series of laboratory investigations designed to determine the dependence of solid transport on pipe geometry, water usage and solid dimensions and mass. 
During an extensive laboratory test program undertaken at Brunel University, U.K., as a component of a hospital drainage system study for the U.K. Department of Health, it was apparent that the transport characteristics of a maternity pad solid in a $100 \mathrm{~mm}$ diameter UPVC, glass or cast iron waste pipe could be expressed in the form

$$
\mathrm{V}=\mathrm{C}_{1}-\mathrm{C}_{2} 1 \sqrt{\mathrm{L} / \mathrm{G}}
$$

where

$\mathrm{V}=$ solid velocity at distance $\mathrm{L}$ from pipe entry

$G=$ pipe gradient

$C_{1}=$ 'extrapolated solid velocity at $L=0$ from equation ( 1 ), the units of this constant being $\mathrm{m} / \mathrm{s}$.

$C_{2}=$ solid deceleration coefficient with respect to distance $L$, the units of this constant being $\mathrm{m}^{1 / 2} / \mathrm{s}$.

These results are represented in figure 1 and are more fully explained in [1,2], together with an analysis of the flow mechanisms observed.

The model solid employed was a commercially available maternity pad, or heavy duty sanitary napkin, dimensions $270 \mathrm{~mm}$ x $60 \mathrm{~mm} \times 20 \mathrm{~mm}$, water saturated weight 250 gms, currently supplied to U.K. hospitals, an acceptable, cheap model solid for the very large number of tests carried out.

Observation of fecal and other waste materials in hospital installed drainage systems also displayed this solid transport characteristic equation, the values of $C_{1}$ and $C_{2}$ varying with the solid type [3]. This reproduction in practice of the observed laboratory results indicated the possibility of representing typical system loading by a suitable choice of model solids of a type similar to the maternity pad. It was decided to undertake an analysis of the factors determining the values of $C_{1}$ and $C_{2}$, this survey to include both pipe size, w.c. flush volume and solid geometry and mass parameters.

The maternity pad solid was also employed for a series of tests designed to illustrate the effect of pipe diameter and w.c. flush volume, the test results confirming the relationships illustrated in figure 1, but displaying a more rapid deceleration as flush volume decreased [4].

The extension of this program to geometry and mass effects was made possible by a request from the U.K. Association of Sanitary Protection Manufacturers for assistance in developing a flushability criterion for w.c. disposal of sanitary towels (napkins), diapers and tampons. Appendix 1 reproduces a recent paper [5] describing this test program. 
At the culmination of the test programs, a total of some 30 solid geometry/mass combinations had been tested with corresponding data for $100 \mathrm{~mm}$ and $75 \mathrm{~mm}$ pipe diameters and w.c. flush volumes ranging from the U.K. standard of 9.1 liters down to 4 liters. This body of data was considered sufficient to test the dimensional analysis based on the solid/system parameters presented below. 
3. ANALYSIS OF THE VARIABLES GOVERNING SOLID TRANSPORT

As shown by figure 1 and equation (1) the velocity profile against distance travelled along a waste pipe may be expressed as:

$$
\mathrm{V}=\mathrm{C}_{1}-\mathrm{C}_{2} \sqrt{\mathrm{L} / \mathrm{G}}
$$

Non dimensionally this may be expressed as

$$
\frac{v}{\sqrt{g x}}=\frac{C_{1}}{\sqrt{g x}}-C_{2} \sqrt{y / g x} \sqrt{L / y G}
$$

where

$$
\begin{aligned}
g & =\text { acceleration due to gravity } \\
x, y & =\text { suitable characteristic lengths }
\end{aligned}
$$

Equation (2) may be written as

$$
\mathrm{v}^{*}=\mathrm{K}_{1}-\mathrm{K}_{2} \sqrt{\mathrm{L} / \mathrm{yG}}
$$

where

$V^{*}=$ is a non dimensional group having the same form as Froude Number.

The terms $K_{1}, K_{2}$ may be expressed as functions of the solid and pipe system as follows:

$$
k_{1}, K_{2}=f_{1}\left(l, t, w, \rho_{s}, D, F, F_{B}, \rho_{w}\right)
$$

where

$$
\begin{aligned}
\ell & =\text { solid length } \\
w & =\text { solid width } \\
t & =\text { solid thickness } \\
\rho_{S} & =\text { solid density }
\end{aligned}
$$




$$
\begin{aligned}
D & =\text { pipe diameter } \\
F & =\text { total flush volume } \\
F_{B} & =\text { flush discharge behind the solid } \\
P_{W} & =\text { water density }
\end{aligned}
$$

Excluded from (4) is the pipe roughness effect as the bulk of the data available refers to UPVC pipe systems.

Thus, the nine variables involved yield six dimensionless groups:

$$
\mathrm{K}_{1}, \mathrm{~K}_{2}=\mathrm{f}_{2}\left(\frac{\ell}{\mathrm{D}}, \frac{\mathrm{w}}{\mathrm{D}}, \frac{\mathrm{t}}{\mathrm{D}}, \frac{\mathrm{F}}{\mathrm{F}_{\mathrm{B}}}, \frac{\rho \mathrm{s}}{\rho_{\mathrm{w}} \mathrm{F}_{\mathrm{B}}}\right)
$$

The solid width $w$ may be used as the length characteristic $x$ in equation (2) while the pipe diameter $D$ would be appropriate as the $y$ length term.

Approved test methodology would require the study of the dependence of $\mathrm{K}_{1}, \mathrm{~K}_{2}$ on each group in turn, requiring the other four to be held constant. Unfortunately, this was not possible as the model geometry terms were dictated by human anatomy and fashion. Similarly, the mass terms were dictated by physiology. Within these limits the various contributing manufacturers produce a range of towels as shown by table 1 .

A general equation of the form

$$
k_{1}, k_{2}=\left(\frac{l}{D}\right)^{i}\left(\frac{w}{D}\right)^{j}\left(\frac{w t}{D^{2}}\right)^{k}\left(\frac{F}{F_{B}}\right)^{m}\left(\frac{\rho}{\rho_{w} F_{B}}\right)^{n}
$$

was postulated and data fit tested by means of a computer program run on the NBS Center for Building Technology's Perkin Elmer 732 Computer. The results of the data fit trials are discussed below. 
Appendix 1 describes the test installation employed for the flushability criteria development work at Brunel University. The rig consisted of $14 \mathrm{~m}$ length of $100 \mathrm{~mm}$ diameter transparent UPVC waste pipe set at a gradient of 1/80. Solid velocity was recorded over six $300 \mathrm{~mm}$ lengths at $2 \mathrm{~m}$ intervals along the test pipe by means of photoelectric cells and electronic timers.

The water volume vs. time profile at discharge from the $14 \mathrm{~m}$ pipe length was recorded via a linear displacement transducer driven by a surface float in the collection tank. Sensitivity was sufficient to record solid entry into the collection tank, yielding the relative volumes of water discharged ahead and behind the solid.

This basic system was also employed in the variation of flush volume and pipe diameter tests as well as being based on the original test system used for the maternity pad investigation represented by figure 1.

Solid dimensions were recorded dry by means of vernier caliper gauge, the average of 20 measurements being taken.

Similarly, dry weight values were based on the average of 20 measurements from a random sample chosen from at least 100 solids. This avoided batch inconsistencies in manufacture.

Saturated weight values were recorded based on an initial study for each product to determine time to achieve full saturation. In most cases saturated weight became a constant at about 30 seconds soaking time.

The effect of varying degrees of presoaking administered to each product is described in appendix 1. For the purposes of this study, this effect is included in the variation in flush water volume discharged behind the solid. 


\section{PRESENTATION OF RESULTS}

Table 1 summarizes the test measurements described above for all the products tested for the Association of Sanitary Protection Manufacturers as well as the Department of Health maternity pad tests and the Brunel University funded reduced water volume and pipe size study.

The derived relationships linking the transport characteristics, $\mathrm{K}_{1}$ and $\mathrm{K}_{2}$ are presented in figures 2 and 3. It will be noted that the groups:

$$
\frac{w}{D}, \frac{t}{D}
$$

have been rewritten as:

$$
\frac{w t}{\pi D^{2} / 4} \quad \text { and } \quad \frac{w l t}{D^{3}}
$$

for the purpose of presenting these relationships. Although this is not strictly necessary, it was felt that this term led to a practical blockage factor that could have a physical interpretation.

It will be seen from table 1 that all products tested are referred to by a code $A B$. In this code $A$ refers to the manufacturer and $B$ is a number allocated to each product tested. Code 34 indicates the maternity pad solid. . 
A general format for a possible relationship based on the analysis presented may be represented by

$$
k_{1}, K_{2}=\left(\frac{l}{D}\right)^{1}\left(\frac{w}{D}\right)^{j}\left(\frac{w t}{D^{2}}\right)^{k}\left(\frac{F}{F_{B}}\right)^{m}\left(\frac{s}{\rho_{w} F_{B}}\right)^{n}
$$

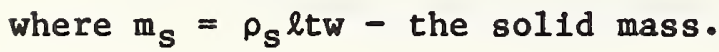

Due to an inability to deal with each group in isolation it was decided to investigate the dependence of the measured transport characteristics on pipe blockage factor, as defined above, and w.c. performance, as defined by the ratio of water discharged behind the solid to the total volume available, $\mathrm{F}_{\mathrm{B}} / \mathrm{F}$.

Referring to the w.c. efficiency, as defined by $F_{B} / F$ it was found that the ratio was dependent on the total flush volume avallable as might be expected from an analysis of the forces acting to discharge the solid initially at rest in the pan from the w.c. bowl.

Equation 6 was therefore restructured as:

$$
\mathrm{K}_{1,2} \cdot\left(\frac{D}{l}\right)^{1} \cdot\left(\frac{D}{w}\right)^{j} \cdot\left(\frac{D}{t}\right)^{k} \cdot\left(\frac{\rho F B}{m_{S}}\right)^{n}=\left(\frac{w t}{\frac{\pi D^{2}}{4}} \frac{F}{F_{B}}\right)^{p}
$$

and a series of computer trial fits were investigated to determine a suitable form for the relationship.

Inspection of equation 7 would suggest that the relationship tends to infinity as the $x$ or $y$ ordinate tends to zero, as shown by figures 2 and 3 .

A number of characteristic points may be identified:

1. Table 1 indicates that the available spread of terms $\mathrm{D} / \mathrm{L}$ and $\mathrm{D} / \mathrm{w}$ is much less than that of the term $D / t$. This is a result of product design criteria as described previously.

2. As the blockage factor decreases and tends to zero so the values of the $\mathrm{K}_{1}$ or $\mathrm{K}_{2}$ multiplier terms increase resulting in the $\mathrm{y}$ ordinate tending to infinity.

3. As pipe diameter decreased the value of the $\frac{w t}{\pi D^{2} / 4} \cdot \frac{F}{F_{B}}$ term increases, a group of points representing $75 \mathrm{~mm}$ pipe diameter results in figures 2 and 3 illustrate this. 
4. At values of $x$ ordinate below 0.1 the $K_{1,2}$ multiplied $y$ ordinate term increases rapidly and hence is more susceptible to measurement errors. As shown by table 1 the products represented by these results, Codes 41 , 61 , and 75 had thin profiles, 2 to $7 \mathrm{~mm}$, so that measurement errors have the potential for multiplication. Similarly, the true blockage within the pipe could be underestimated due to the solid taking up the local water surface profile slope, hence increasing its projected area in the flow direction.

5. Model solid dimensions were recorded dry for practical reasons. The true thickness of the solid could vary in the saturated state in the pipe. This would only be a serious source of measurement error for the thinner solids.

6. Saturated weights were recorded following some 30-40 records soaking in all cases. It was felt that these figures could be used with confidence in the data fit trials described.

As shown in figures 2 and 3, the transport characteristics of the chosen model solids may be represented by equations of the form

$$
\mathrm{K}_{1} \text { or } \mathrm{K}_{2}=\mathrm{K} \frac{\ell}{\mathrm{D}} \frac{\mathrm{w}}{\mathrm{D}} \frac{\mathrm{t}}{\mathrm{D}}\left(\frac{\mathrm{m}}{\frac{\mathrm{s}}{\rho_{\mathrm{w}} \mathrm{F}_{\mathrm{B}}}}\right)^{2} \frac{\mathrm{wt}}{\frac{\pi \mathrm{D}^{2}}{4}} \cdot\left(\frac{\mathrm{F}}{\mathrm{F}_{\mathrm{B}}}\right)^{\mathrm{q}}
$$

where

$\mathrm{K}$ is a positive constant

$q$ is a negative index

and $1=j=k=1 ; n=2$.

It should be noted that the flush volume behind the solid included in these relationships was recorded at discharge from the $14 \mathrm{~m}$ pipe at a gradient of 1/80. Strictly, this figure should be appropriate to the solid discharge from the w.c. to be truly independent of pipe slope. However, as these relationships are to be used as calibration coefficients to model known system loading, this is acceptable.

The results presented are limited to UPVC waste pipe at this stage. Although tests with cast iron pipe were included in [1], these results applied only to the maternity pad solid. Tests comparing glass, UPVC and cast iron $100 \mathrm{~mm}$ diameter pipe transport indicated that surface roughness alone was not sufficient to explain transport variations as the smooth bore glass yielded transport results between UPVC and cast iron.

Figure 4 represents the waste solid deposit positions as predicted by writing $\mathrm{V}=0$ in equation $3,1 . e$. ,

$$
\sqrt{\mathrm{L} / \overline{D G}}=\mathrm{K}_{1} / \mathrm{K}_{2}=\mathrm{K}_{3}
$$


and from figures 2 and 3

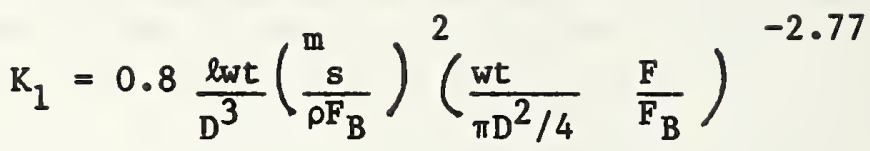

$$
\begin{aligned}
& K_{2}=1.04 \frac{l w t}{D^{3}}\left(\frac{m}{\rho F_{B}}\right)^{2}\left(\frac{w t}{\pi D^{2} / 4} \frac{F}{F_{B}}\right)^{-2.3}
\end{aligned}
$$

hence

$$
\mathrm{K}_{3}=0.77\left(\frac{\mathrm{wt}}{\pi \mathrm{D}^{2 / 4}} \frac{\mathrm{F}}{\mathrm{F}_{\mathrm{B}}}\right)^{-0.47}
$$

In practice the solid deposition may occur from any velocity below about 0.2 $\mathrm{m} / \mathrm{s}$ due to its retardation by any pipe discontinuity, such as a coupling or joint. At velocities in this range the solid motion is entirely due to the water head differential across the solid and any retardation of the solid allows the driving water to leak past the solid, thus, destroying the driving hydrostatic force. 


\section{CONCLUSIONS}

The test results presented for a wide range of geometrically similar solids allow their transport characteristics to be expressed in terms of solid geometry and mass and drainage system parameters including pipe diameter and w.c. flush volume.

These relationships confirm the dependence of solid transport on the $\sqrt{\mathrm{L} / G}$ term during the deceleration phase. Experimental work has identified this phase as being predominant in the internal building branch drain situation.

The ability to predict model solid performance from these relationships in combination with the observation currently being undertaken in installed drainage systems will allow laboratory based test programs to both model system loading and predict the effect of design changes on system performance. 


\section{REFERENCES}

1. Swaffield, J. A. and Wakelin, R. H. M., Observation and Analysis of the Parameters Affecting the Transport of Waste Solids in Internal Drainage Systems, Journal Institution Public Health Engineers, U.K., November 1976.

2. Swaffield, J. A. and Wakelin, R. H. M., A Study of the Transport of Solids in Internal Drainage Systems, CIBW62 Seminar, Oslo, May 1977.

3. Bokor, S. D. and Swaffield, J. A., Application of Laboratory Test Techniques to Building Drainage Design, IPHE Seminar, Brunel University, U.K., June 1980.

4. Marriot, B. S. T. and Swaffield, J. A., Effect of Reduced Volume w.c. Flush on Internal Drainage Performance, CIBW62 Seminar, Brussels, October 1978.

5. Howarth, G., Wakelin, R. H. M., and Swaffield, J.A., Development of a Flushability Criterion for Sanitary Products, CIBW62 Meeting, Brunel University, June 1980. 
$\dot{u} *$

$\dot{0}$

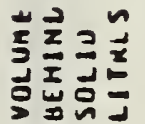

I

일

닐

$\div \leq$

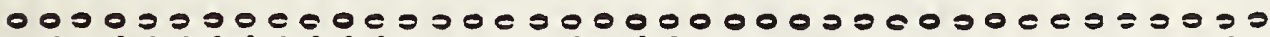

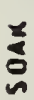

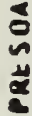

1

$\dot{\div}$

竞

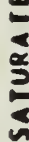

$\hat{\mathbf{x}}$

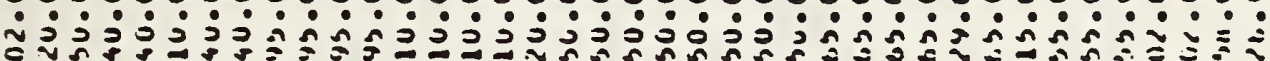

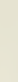

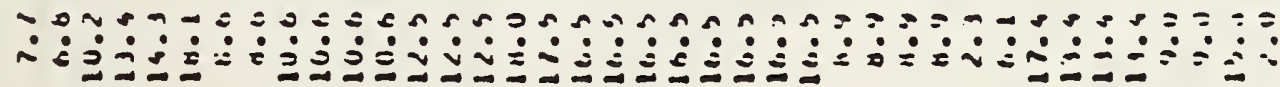

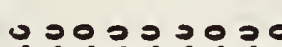
in:

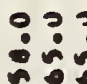

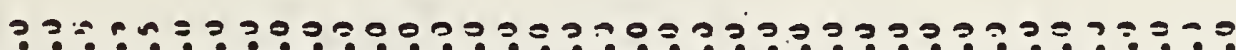
n.

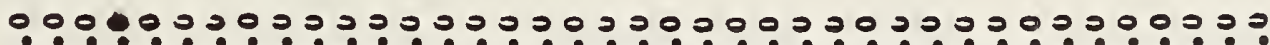
$\frac{2}{2}$

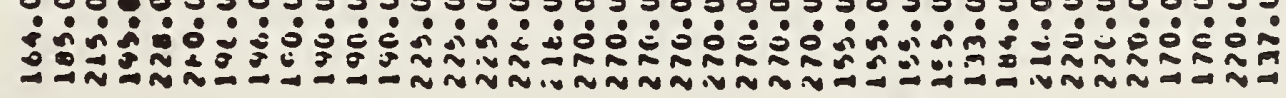

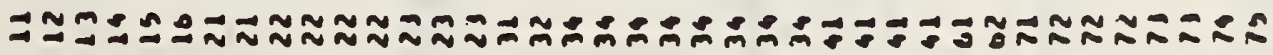

$\equiv$

$\mathbf{z}$

$\underline{\Sigma}$

ड़

2

$\frac{2}{2}$

$=\hat{n}$

- $\overline{\bar{z}}$

논:

도

$\simeq \pm=$

$\vdots \equiv \frac{1}{3}$

$\div 20$

$-6$

르

$\dot{4}=\dot{3}$

声:

$\infty \cdots$

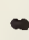

ริ

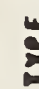

㑒 $\approx$

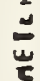




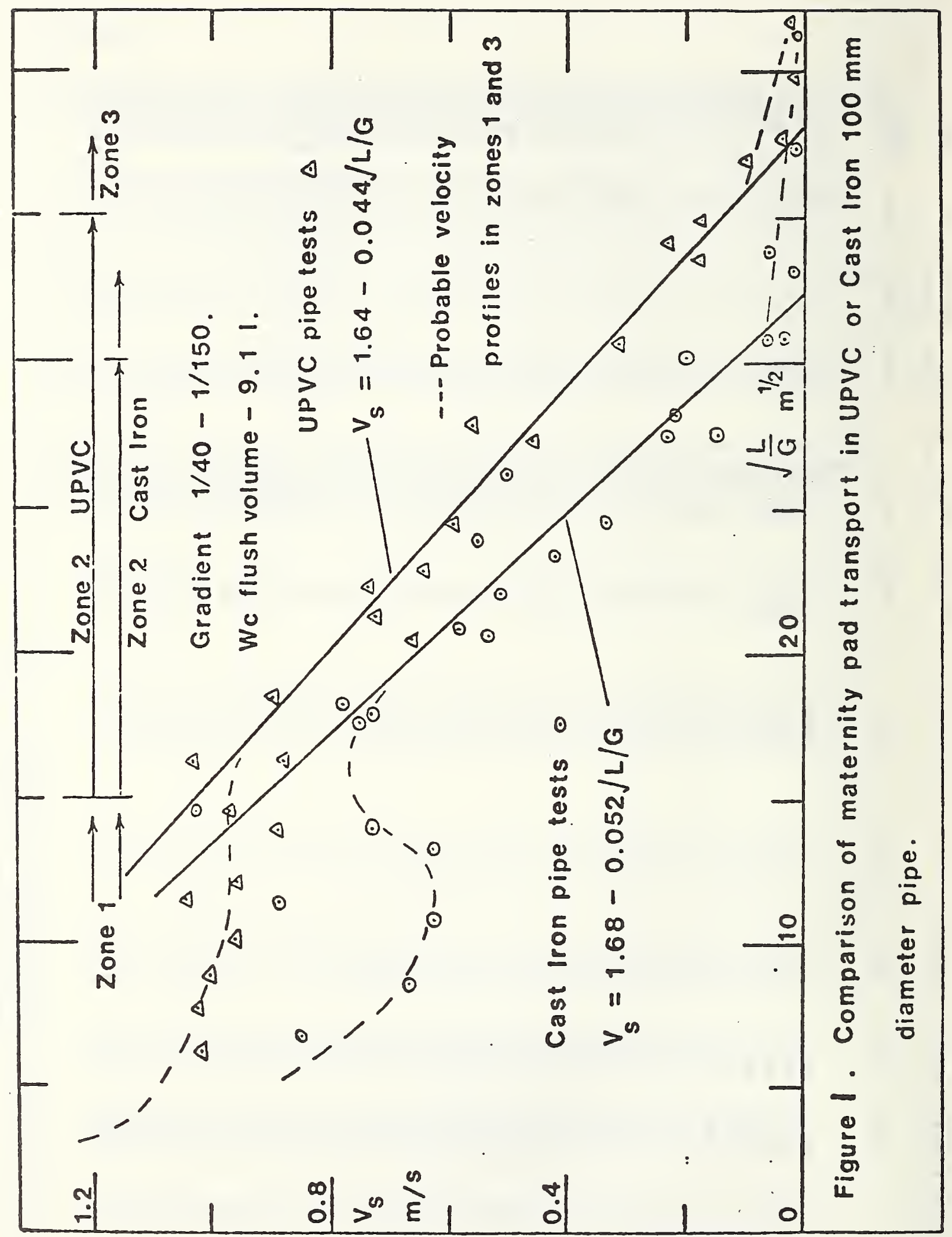




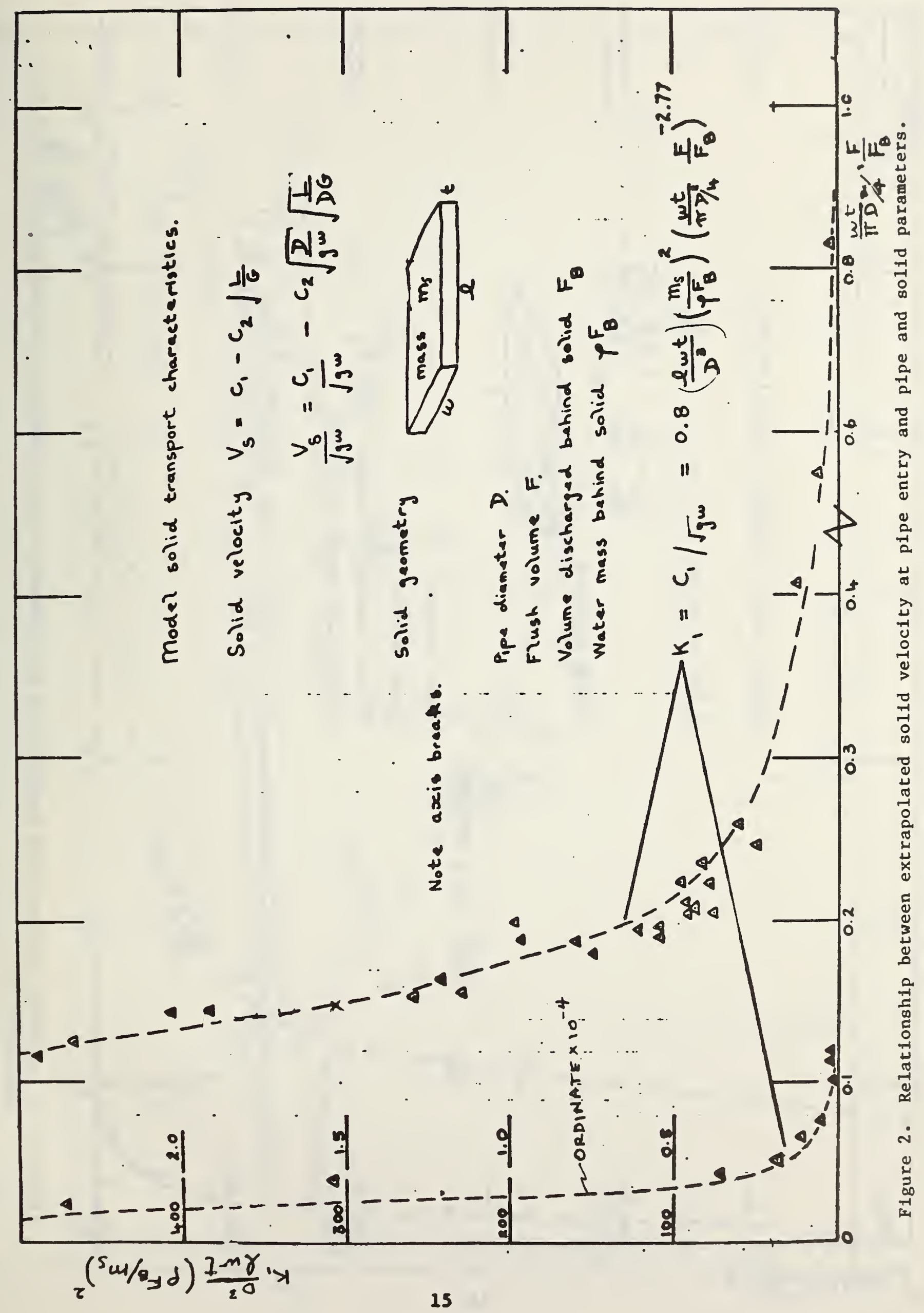




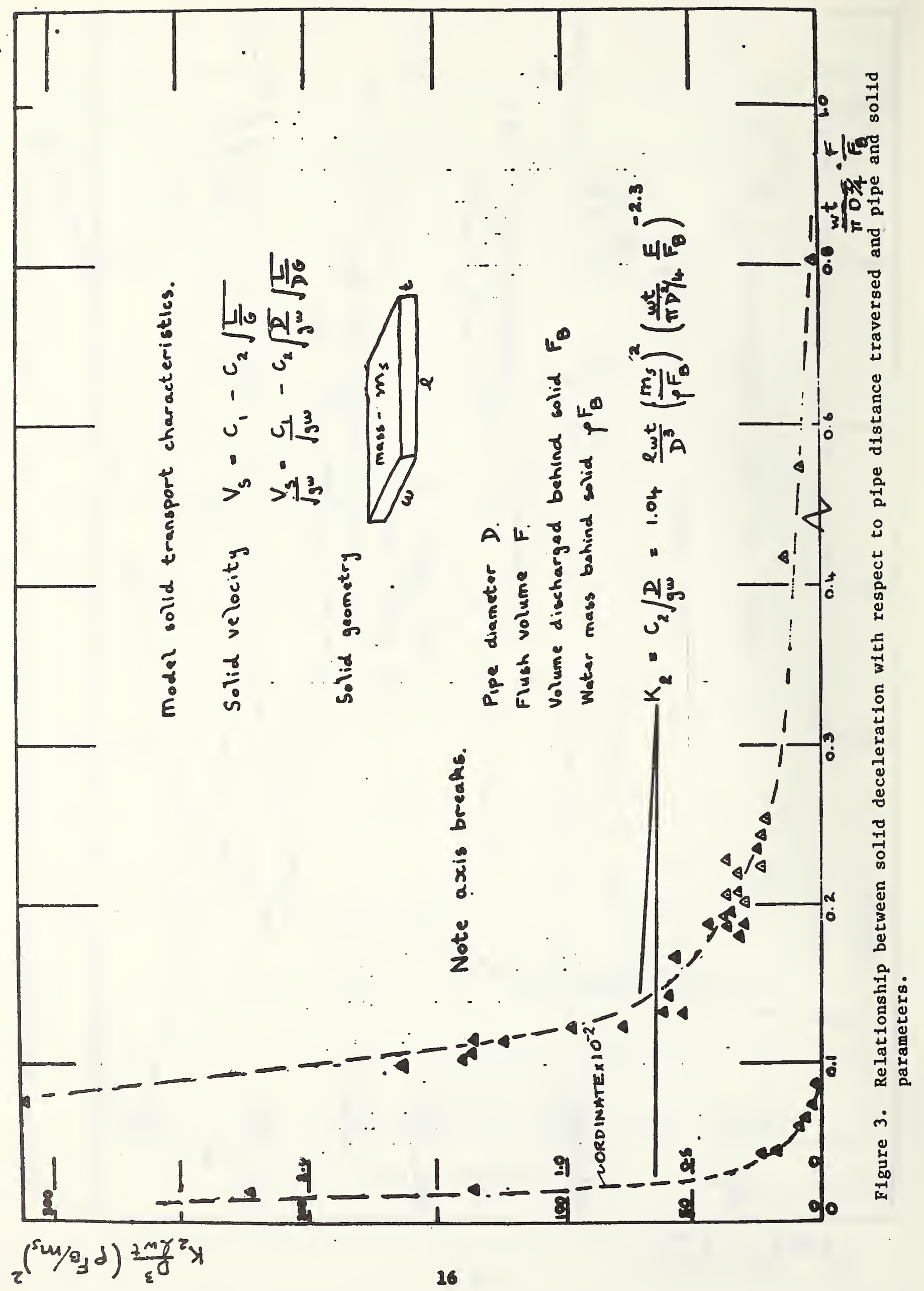




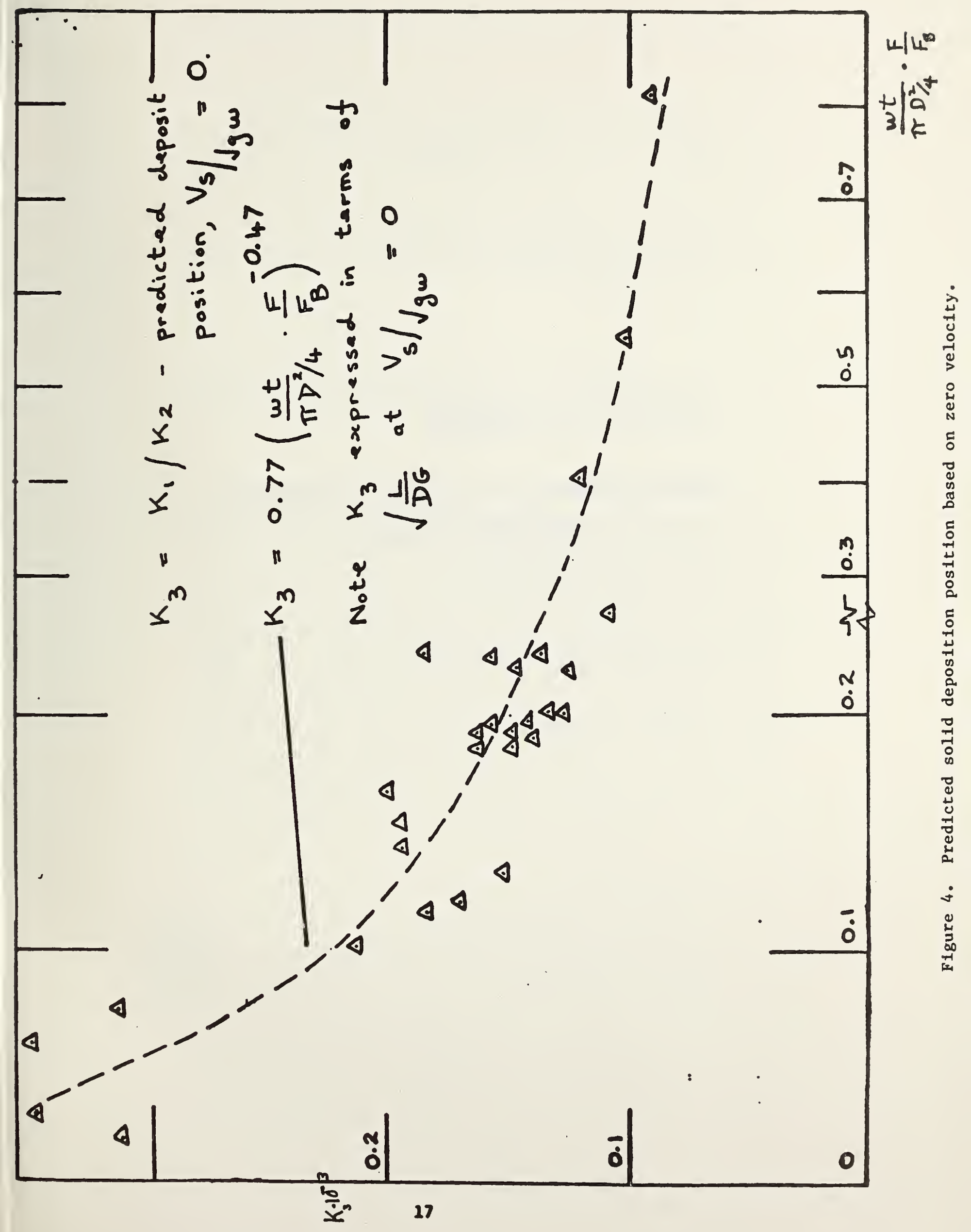



APPENDIX 1

\section{Flushability Criteria for U.K. Sanitary Products Reprint of Reference 5}


DRAINAGE AND WATER SUPPLY FOR BUILDINGS

A TWO DAY SEMINAR ON CURRENT RESEARCH AND FUTURE NEEDS AND OBJECTIVES

BRUNEL UNIVERSITY, UXBRIDGE, ENGLAND JUNE 3 AND 41980

DEVELOPHEFIT OF A FLUSHABILITY CRITERION FOR SANITARY PRODLICTS

DR, G. HOWARTH

TECHNICAL DIRECTOR, SOUTHALLS（BIRMINGHAM）LTD

DR. R,H.M. WAKELIN

DR, J,A. SWAFFIELD

LECTURER AND SENIOR LECTURER RESPECTIVELY

DRAINAGE RESEARCH GROUP

DEPARTMENT OF BUILDING TECHNOLOGY

BRUNEL UNIVERSITY

ORGANISED BY

DRAINAGE RESEARCH GROUP

DEPARTMENT OF BUILDING TECHNOLOGY

BRUNEL UNIVERSITY 
DEVELOPMENT OF A FLUSHABILITY CRITERION FOR SANITARY PRODUCTS

by

Dr. G. Howarth, Technical Director,

Southalls (Birmingham) Ltd

Dr. R.H.M. Wakelin

and

Dr. J.A. Swaffield

Lecturer and Senior Lecturer respectively

Drainage Research Group

Department of Building Technology, Brunel University.

\section{SUMMARY}

The development of a set of flushability criteria for sanitary protection products is described. The need for a criterion is stated and the initial test work undertaken to establish the required pass levels is fully described.

The results show that the form of earlier empirical relations developed at Brunel to link waste solid velocity to pipe length and gradient apply to a wide range of solid size and shape parameters.

Finally the agreed test specification is presented together with a view of future development work in this area. The results collected over the test period are to be analysed further to identify any correlation between transport characteristics and size and shape parameters. 


\section{INTRODUCTION}

The Association of Sanftary Protection Manufacturers (ASPM) is a body formed to represent the views of, and set agreed standards amongst, all members of the industry. One of these standards to be examined was the term "flushable" which is printed on nearly all the packages of sanitary protection products.

These sanitary protection products can vary widely in size, construction and weight, as follows:-
(a) Tampons
2 to 5 grammes and 5 cms long
(b) Towels (Napkins) - Mini
4 to 8 grammes $15 \mathrm{cms}$ long
Towels
6 to 20 grammes
$20 \mathrm{cms}$ long
(c) Panty Shields
2 to 4 grammes
15 cms long

The towel raw materials are basically "cellulose" - fillings of tissue, fluffing pulp with a non-woven cover. There is sometimes a plastic film inside the towel as a fluid barrier. Plastic can also be used as a release tape to cover the pressure sensitive adhesive on the back of the towel. The non-woven cover can be very specialised - either completely non-absorbent polyesters or a "flushable" cover which disperses after some time in water. Rayon or a rayon/cotton mixture is the usual fibre for tampons.

The actual number of products used per day is estimated as follows: -

\begin{tabular}{|l|c|c|}
\hline \multicolumn{2}{|c|}{ PRODUCT } & $\begin{array}{l}\text { NO. OF PADS } \\
\text { MILLIONS/DAY }\end{array}$ \\
\hline \multirow{3}{*}{ TAMPONS } & Mini & 2.49 \\
\hline \multirow{3}{*}{ TOWELS } & Looped & 0.62 \\
\cline { 2 - 3 } & Self Adhesive & 1.06 \\
\cline { 2 - 3 } & & 2.28 \\
\hline
\end{tabular}


Our own surveys have shown that approximately 80 of of the ladies dispose of these products by flushing lown the toilet i.e. five million products per day. There are various flushability instructions given on the packs.

"Simply flush it away - all in one plece"

"Just remove the cover and flush away separately"

"Completely flushable (no need to pull apart), fust flush the whole towel away"

"Remove outer covering, empty contents and flush away. Then flush cover separately"

"Do not flush"

These instructions support the general public's view that "flushable" means it will disappear down the toilet. However the ASPM wanted to be more specific in its definition of "flushable".

\section{Flushability Definition}

The Technical Committe of the ASPM considered that the definition was really in two parts - the product should flush from the pan but also cause no problems in the subsequent drainage system. Various Research Establishments were contacted, with the following general conclusions :

(a) Drain blockages were in fact due in the main to a drain fault i.e. poor joints or faulty pipework.

(b) Although the BSI minimum flush volume is 9 litres, in the majority of WC systems the volume is 12 litres. However there are moves to reduce this minimum standard and in addition dual flush and controlled flush systems could be introduced.

(c) If the towels managed to get into the main sewage pipe trunking system no problems should occur.

(d) The amount of plastic in the products is unlikely to cause a problem at the sewage farm.

Therefore it seemed reasonable to concentrate on a method of measuring the failure of the product to leave the WC and also the "state" of the product after travelling some distance in the pipework. ASPM member companies had already simple WC systems plus a collection device for evaluating flushability. Unfortunately these were non-standard methods with no scientific measurements.

However it was possible using the test rig developed by the Drainage Research Group at Brunel University to define both a test method and specification. In summary they have: . 
(a) A test rig available consisting of a WC pan, connected to a short vertical section and then 14 metres of horizontal pipe. The velocity of the solid can be measured at various points along the pipe length and the volume of water ahead of the solid measured.

(b) Developed a theory of solid transport which will allow them to predict the drainage performance of a solid at any gradient of pipe and various types of pipe.

\section{Flushability Specification}

A 100 samples should be tested on the BRUNEL rig and the following criteria must be satisfied.

(a) WC failures: A maximum of six WC failures plus pipe stoppages below 10 metres are allowed i.e. 3 WC failures +3 stoppages below 10 metres.

(b) If a WC failure occurs then the product must flush greater than 10 metres along the pipework on the second flush.

\section{Fl.ushability Rig and Method}

\section{TEST EQUIPMENT}

A. The test pipe consisted of $7 \times 2 \mathrm{~m}$ lengths of $100 \mathrm{~mm}$ bore UPVC discharge pipe connected at its upstream end to a vented discharge Twyfords P-trap WC via a Terrain UPVC $104^{\circ}$ junction and $922^{\circ}$ UPVC bend. The centre line of the UPVC pipe was 300mm below simulated fioor level at this connection.

The pipe is supported over its whole length by means of two $7 \mathrm{~m}$ long lightweight aluminium ladders. Initial level setting by use of a surveyor's level ensured later gradient adjustments to an accuracy of $0.5 \mathrm{~mm}$. A gradient of $1 / 80$ was used for all the reported tests. The performance of the test pipe was monitored by recording the velocity of the waste solids at six points along the pipe length. Table 1 indicated the positions chosen. The discharge was collected at the downstream end of the test pipe by a tank equipped with a depth recording linear displacement transducer linked to a pen recorder. From the volume vs time output of this system the quantity of water entering the collection tank ahead of the solid could be accurately measured.

Table 1 SUMMARY OF VELOCITY MEASURING POSITIONS

Test Code

B. Velocity Position Distance from WC (m) Separation photocells

$\begin{array}{cccccc}1 & 2 & 3 & 4 & 5 & 6 \\ 3.05 & \begin{array}{c}5.08 \\ -0.3 m\end{array} & 7.11 & 9.15 & 11.18 & 13.21\end{array}$




$\begin{array}{lllllll}\text { C. Velocity Position } & 1 & 2 & 3 & 4 & 5 & 6 \\ \text { Distance from wC (m) } & 3.05 & 5.08 & 7.11 & 9.15 & 11.18 & 13.21 \\ \text { Velocity measuring length } & & -1.0 m & & & & \end{array}$

\section{SAMPLE PREPARATION}

D. (a) If an adhesive backed towel is tested, the release strip must be taken off and towel placed on a clean, fresh section of "pantie" cloth. (The cloth to be defined and sample at Brunel). A 2 kilogramme weight $(3 \mathrm{~cm}$ wide $\times 20 \mathrm{~cm}$ long) is placed on towel for 90 seconds. The towel to be then peeled longitudinally from the cloth. If however on dropping the towel into the pan it sticks to the side of pan due to the adhesive then these results should be ignored.

E. (b) The product should be pre-soaked with water

$\begin{array}{lll}\text { Tampons } & - & \text { no pre-soak } \\ \text { Panty shields } & - & 2 c c \\ \text { Mini towel } & - & 6 c c \\ \text { Towel } & - & 20 c c\end{array}$

The water should be applied over the middle third of the product and to avoid excess running off the surface it should take 1 minute to apply the fluid.

F. (c) The product must be torn, if necessary, as defined on the package.

SAMPLE PLACEMENT

G. (a) The product should be held vertically and the bottom of the pad (not loops) should be level with the rim of the toilet and in the centre of the basin.

H. (b) The product is dropped into the pan and 20 seconds later the toilet is flushed.

MEASUREMENT

I (a) WC FAILURE: If the product fails to leave the toilet, this is noted plus the number of flushes required to remove the product.

J. (b) VELOCITY: The velocity is recorded at various points along the pipework system as defined in the test equipment. It may be necessary to change the method of measuring the velocity if the solid disperses.

K. (c) STOPPAGE DISTANCE: If the product stops in the pipework the distance from the WC is recorded.

L. (d) i VOLUME OF FLUID AHEAD: This is recorded as it should confirm a satisfactory flush. It is measured by a signal from the depth recorder in the collection tank at the end of the pipework.

NUMBER OF TESTS:

A minimun of a 100 tests should be completed. 
DRAIMAGE RISEARCH GRCUF,

DEPARTMERT CF RUILDI:! TECFNOLOGY,

BPUNEL U!!IVELSITY,

UYBRIDGE, NIDIIESEX. (Tel: Uxbridge 37188 ext. 344 \& 359)

The attached test snecification details the test rig and methods used to determine the acceptance of the towel for disposal by lic flushing. The operative paragraphs of the specification are listed where apuropriate:-

Towel type

Dr. White's Panty Pads Suner Plus

Trst equipment

A

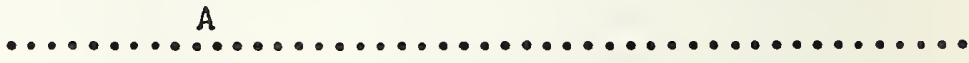

Velocity measurement

C

positions

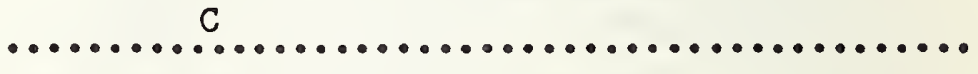

Sample preparation

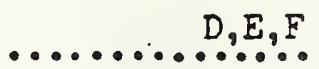

Sample placement

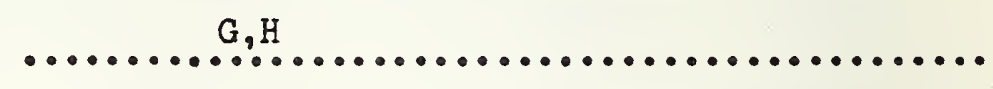

Measurements

$$
I, J, K, I
$$

Number of lic

100

flushes

WC flush frilures

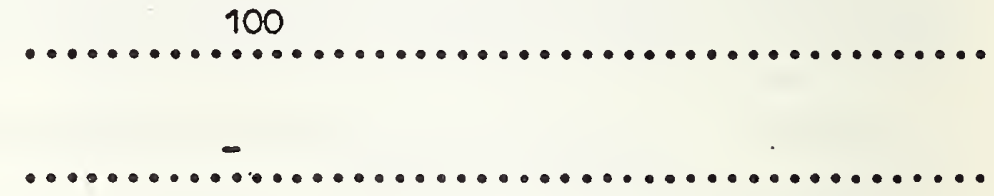

Wic 2nd flush failures

Theoretical zero velocity pipelength

based on $V=C_{1}-C_{2} \sqrt{I} / G$

$\sqrt{\mathrm{L} / \mathrm{G}}=62.44$

$\mathrm{L}=48.7 \mathrm{~m}$ at $1 / 80$

Stompage distances recorded

Mcan $=-$ Max $=-$ Min $=-M D=-$

lumber of stoppages in pipe

0

Volume discharged ahead

of solid

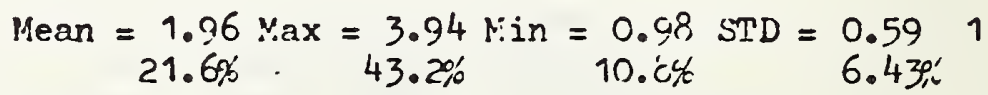

Comments on test performance

- No. מroblems encounternd duringr lic tonts.

mhis product casses the test specificntion 
In carrying out this investigation to determine a flushability method various assumptions have been made and certain facts found:-

(1) WC Pan: A BSI P-trap WC was used as the majority of U.K. houses would have this type of toilet. At this stage siphonic systems have not been investigated.

(2) Flush Volume: The current British Standard stipulates a minimum flushing volume of 9 litres, and this was used in the test method. However it is more likely that the volume is $11 / 12$ litres in the home. There are available reduced volume flush systems and controlled flush systems, none of these have been investigated.

(3) Cover Flushing: In the past it has been recommended on those towels which have the cover torn that the cover is flushed separately. It was found better to flush cover and contents together.

(4) Air Entrapment: One of the major factors in poor performance was air entrapment in the product which forced the product to float.

(5) Product Placement: It was decided to specify the position from which the product is dropped so as to try to eliminate any product falling onto the sides of the pan, and prevent any bridging effect on long products.

(6) Pre-soak: It was found that the product performance in general deteriorated if water was added to the product before flushing. Various levels of pre-soaking have been defined.

$\begin{array}{lll}\text { Tampons } & - & 0 \\ \text { Panty shield } & - & 2 c c \\ \text { Mini } & - & 6 c c \\ \text { Towels } & - & 20 c c\end{array}$

(7) Product Shape: At this stage it was felt better to ignore the fact the product could be shaped after use. This was due to the difficulty of reproducing a standard shape, and some evidence that it did not affect the performance.

(8) Sample size: A 100 samples were tested as typical of 6 months usage and it was felt that a 1 in 15 first failure would be acceptable. Care should be taken not to refer the specification as " $6 z$ of towels can fail to leave the WC".

(9) Stoppage Distance 10 metres: There are no British Standards for pipework distances, but it was considered by Brunel that the majority of systems would be less than 10 metres even taking into consideration the twists and turns that sometimes occur. 
In conclusion we do have an industry agreed specification and test method of flushability of sanitary protection products, and hopefully the number of complaints we have from our customers due to flushability problems will reduce from the present one complaint in 100 million products used:

Background to the flushability test work at Brunel

The Drainage Research Group at Brunel have been involved in a fundamental study of the mechanisms of solid transport in above ground drainage systems for a number of years. The initial research, funded by the U.K. Department of Health and Social Security, had led to the establishment for the first time in 1976 of an empirical relationship linking solid velocity to both pipe length travelled and to pipe gradient. Initially (1) this was limited in its application to tests involving maternity pad model solids w.c. flushed under laboratory conditions into a $14 \mathrm{~m}$ lengti of drainage pipework set at gradients from 1/40 to $1 / 200$. Pipe material was initially transparent UPVC although glass and cast iron pipes were also tested. In 1977 further funding from DHSS allowed this programme to continue and to include, in its current stage, the monitoring of installed systems as a means of demonstrating the application of the empirical relationship mentioned above to the wide range of waste transported along a typical drainage system.

The initial relationship linking solid velocity, and hence the probability of deposition, to pipe length and gradient was found to have a form -

$$
V=c_{1}-c_{2} \sqrt{\frac{L}{G}}
$$

where $L$ is the distance travelled along the pipe set at a gradient $G$, over the main length section of w.c. fed branch drain pipe runs. This basic equation was found to apply in the same format to pipes of various materials, e.g. glass, UPVC or cast iron, or to pipes of various cross sectional dimensions and shapes, e.g. $100 \mathrm{~mm}$ and $75 \mathrm{~m}$ diameter and elliptical. Similarly the relationship for various flush volumes with the standard maternity pad solids was found to have a form -

$$
v=\frac{c_{4}-F}{c_{5}}-\frac{c_{6}-F}{c_{7}} \sqrt{\frac{L}{\bar{G}}}-
$$

where $C_{4}-7$ are empirical constants.

Thus when the group was approached by ASPM to aid in the development of a set of flushability criteria for sanitary products that would include solid transport as well as w.c. discharge targets it was clear that the test work envisaged would fit conveniently into the research programe. The Association of Sanitary Protection 
Manufacturers are to be thanked both for entering fully into this co-operation with Brunel and for allowing the test results to be published in an anonymous form.

\section{Development of the test rig}

As the proposed work fitted so closely into the group's programme it was possible to modify one of the existing test pipe runs to form the basis of a flushability test rig. A P-trap w.c. was chosen as the staridard input device based on enquiries on market penetration of various w.C. types. The pipe chosen was $14 \mathrm{~m}$ of $100 \mathrm{~mm}$ diameter transparent UPVC to facilitate the use of standard photo-electric cell and light source instrumentation developed at Brunel to record solid passage along the pipe and nence velocity. Choice of pipe length and gradient were more difficult. After much discussion a gradient of $1 / 80$ and a successful transport length of $10 \mathrm{~m}$ was chosen as reasonable to represent both the more convoluted pipe networks to be found in domestic installation and also the possible worst case formed by an isolated branch w.c., possible in a large building toilet area or a downstairs second w.c. in the domestic sector.

\section{Test programme and results}

The initial objective in 1978 was the confirmation of the application of a relationship of the form of equation 1 to the range of products to be tested, not only in the complete form compatible with the single maternity pad test but also in the torn state compatible with the manufacturer's instructions.

Figures 1 and 2 illustrate typical test results from this initial test series where dry untorn and torn towels were Elushed from the w.c. In all cases the form of equation 1 is confirmed. Under the normal untorn towel test condition the photo-electric cell/ light source pair separation was $0.3 \mathrm{~m}$. However, due to the interaction between multiple solids transported along the pipe, the setting employed for the torn towel tests was increased to $1 \mathrm{~m}$. Although this yields average rather than point velocities the $\sqrt{\mathrm{I} / \mathrm{G}}$ dependence holds, although the yradient of the data equation is much reduced, indicating an improved travel capability.

Figure 3 illustrates the mechanism of multiple solid transport in the drainage pipe, the successive accelerations, both positive and negative, being referred to as the "push me - pull you" effect. At this stage it is perhaps useful to introduce two other measurement terms, namely the flush volume ahead of the solid and the theoretical zero solid velocity value of $\sqrt{L / G}$.

Throughout the tests, and the earlier DHSS work, values of the quantity of water collected at the drain discharge ahead of the solid were recorded by a simple float driven level sensing device in the collection tank. It had been observed that the transport 
characteristics of a solid depend largely on its position in the flush and this is borne out by the ASPM results. Solids that fail the test specification on w.c. failure rate may be shown to have a wide spread of volume ahead results; indeed a w.c. failure may be regarded as a limiting value to these results. In the test rig described values of volume ahead above 308 of the 9 litre flush volume generally lead to problems in satisfying the test specification.

The theoretical zero velocity point from equation 1 is of course given by -

$$
c_{3}=\left(\sqrt{\frac{L}{G}}\right)_{v=0}=c_{0} / c_{2}
$$

In practice deposition may occur from any velocity below about $0.2 \mathrm{~m} / \mathrm{s}$. At these low solid velocities the continuing transport is entirely dependent on the retention of a water volume behind the solid. Any irregularity in the pipe can then retard the solid sufficiently to allow excessive water leakage past and deposition will then occur.

At this stage in the testing programme it was decided to investigate the effect of pre-soaking the towel prior to placing in the w.c. bowl. Available literature would suggest (2) that the volume range of menstrual fluid, consisting of blood, mucin and epithelial cells, should be $8-20 \mathrm{~g}$. It was decided to employ pre-soak water volumes in this range. Figure 4 and Table 2 illustrate the results of these tests. It is apparent that the addition of pre-soak water to the pad resulted in a deterioration in both the w.c. discharge and solid transport properties of the five pads investigated initially. This result at first seemed to be contradictory to the expected mechanism. However, a series of films taken of the pad sinking action in the w.c. bowl prior to flushing led to an acceptable explanation of these results. With an initially dry towel dropped into the bowl the saturation of the towel material occurs by capillary artion so that the level of the water in the saturated towel is always above the bowl water level. This results in a force which draws the towel down into the bowl water.

If the central area of the towel is pre-soaked then two effects are noticeable, firstly the saturated towel tends to cling to the ceramic side of the bowl, and this prevents its inmersion in the bowl water, and secondly the presence of a saturated strip across the towel seems to prevent the capillary action and bowl water does not move up inside the towel past this area. 
Both these effects lead to a later discharge from the w.c. and hence to deterioration of the transport performance in the drainage system. Any tendency to retain air within the towel cover is naturally exacerbated by this failure to totally sink, again leading to late w.c. discharge.

The final simulation considered was a controlled degradation of the adhesive now used on many towels due to the lessening popularity of looped towels. Although this was not a major problem in terms of the number of towel types affected it is obviously necessary to simulate the loss of achesive if for no other reason than to be able to state that any failures to pass the test specification were not due to uncinaracteristic towel adhesion to the w.c. bowl or to the pipe invert.

After much discussion, and some tests involving preheating of towels to degrade the adhesive, a test procedure involving compressing the towel onto representative commercially available female underwear material was developed.

In parallel to the work reported, similar tests were undertaken on tampons and disposable diaper materials. Figure 5 illustrates these investigations and again confirms the $\sqrt{L / G}$ group predominance. One effect that was noticeable with all torn products but more pronounced with diapers was the random discharge from the w.c. In some cases the material was discharged as a continuous, well spread out stream of pulp with no deposition problems. However in some cases the w.c. action resulted in the diaper pulp being discharged in a concentrated mass with rapid deceleration and deposition in the waste pipe. 


\section{CONCLUSIONS}

The tests reported involving sanitary towel products have contributed to the development of the flushability specification presented earlier in this paper. This specification has now been approved by ASPM as the basis for future product testing.

In developing the specification, the decisions taken were based on the widest possible application of the test findings, hence the choice of a relatively cheap and common domestic w.c. type. It may be necessary to investigate further the effects of other w.c. types on the flushability of sanitary products, in particular siphonic w.c. designs may well be a topic for future investigation.

The test results will be analysed further to investigate whether there is a correlation between values of $C_{1}, C_{2}$, and $C_{3}$ and the geometry of the solids and their position in the w.c. flush, as represented by the volume ahead of solid data.

\section{ACKNOWLEDGMENTS}

The Association of Sanitary Protection Manufacturers are to be thanked for making available test results from a programme of work carried out by the Drainage Research Group at Brunel on a consultancy basis.

\section{REFERENCES}

1. Swaffield J.A. and Wakelin R.H.M.

2. Sears W.G.

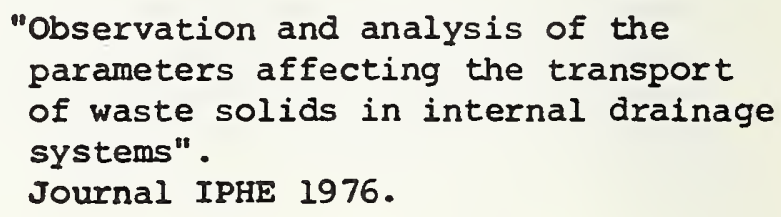
parameters affecting the transport of waste solids in internal drainage systems". Journal IPHE 1976.

"Anatomy and Physiology for Nurses" Edward Arnold 1958. 


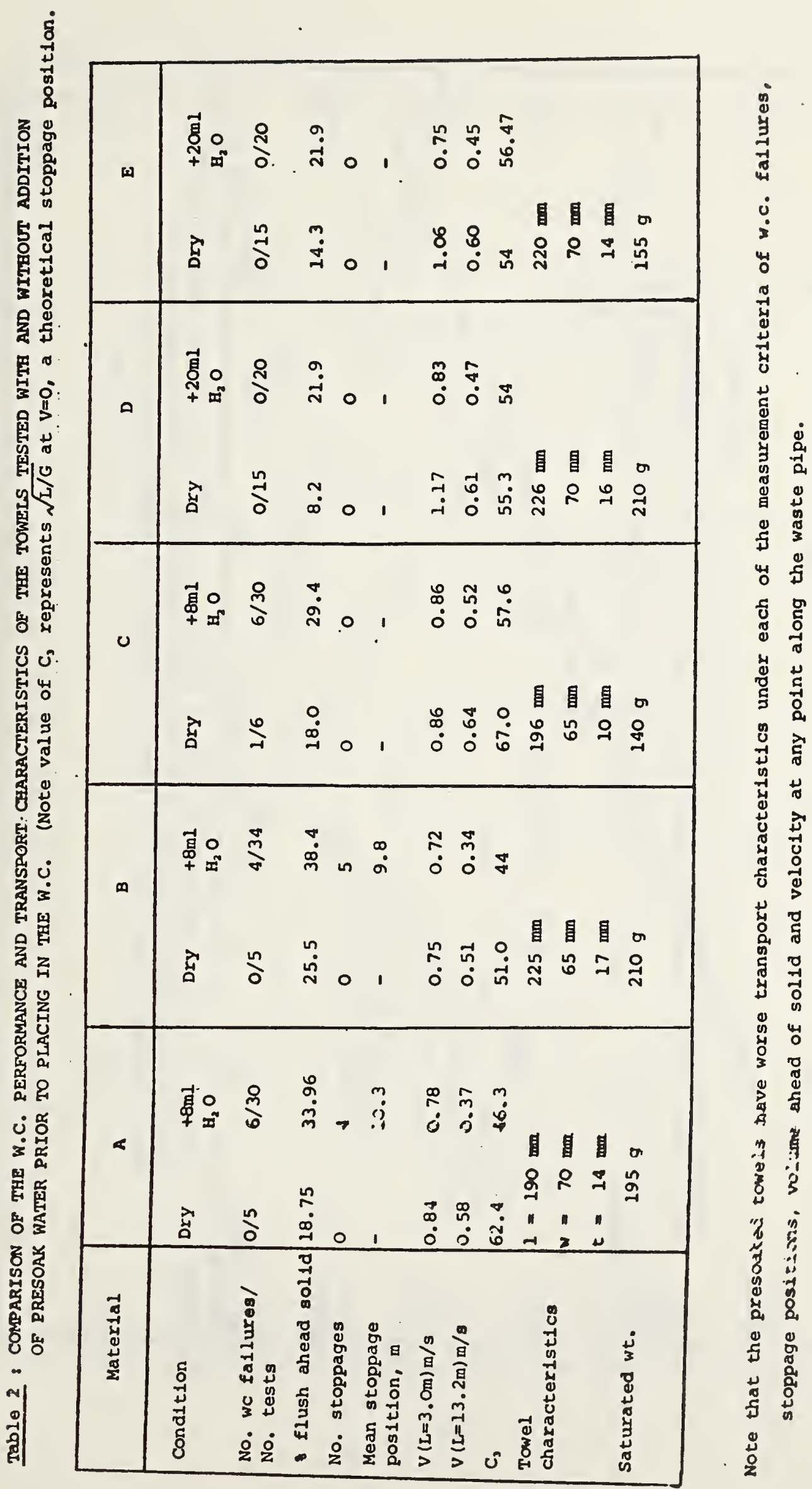




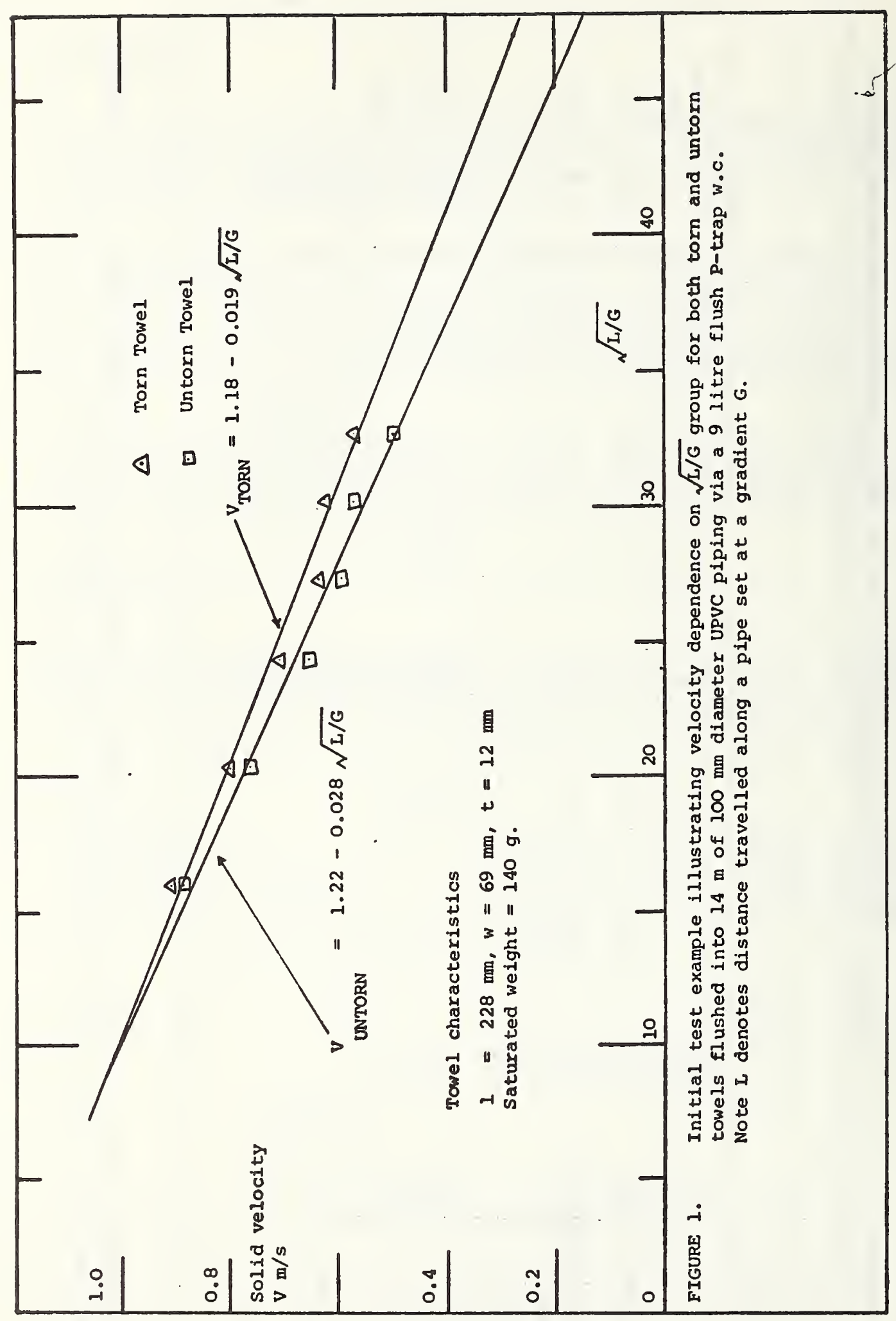




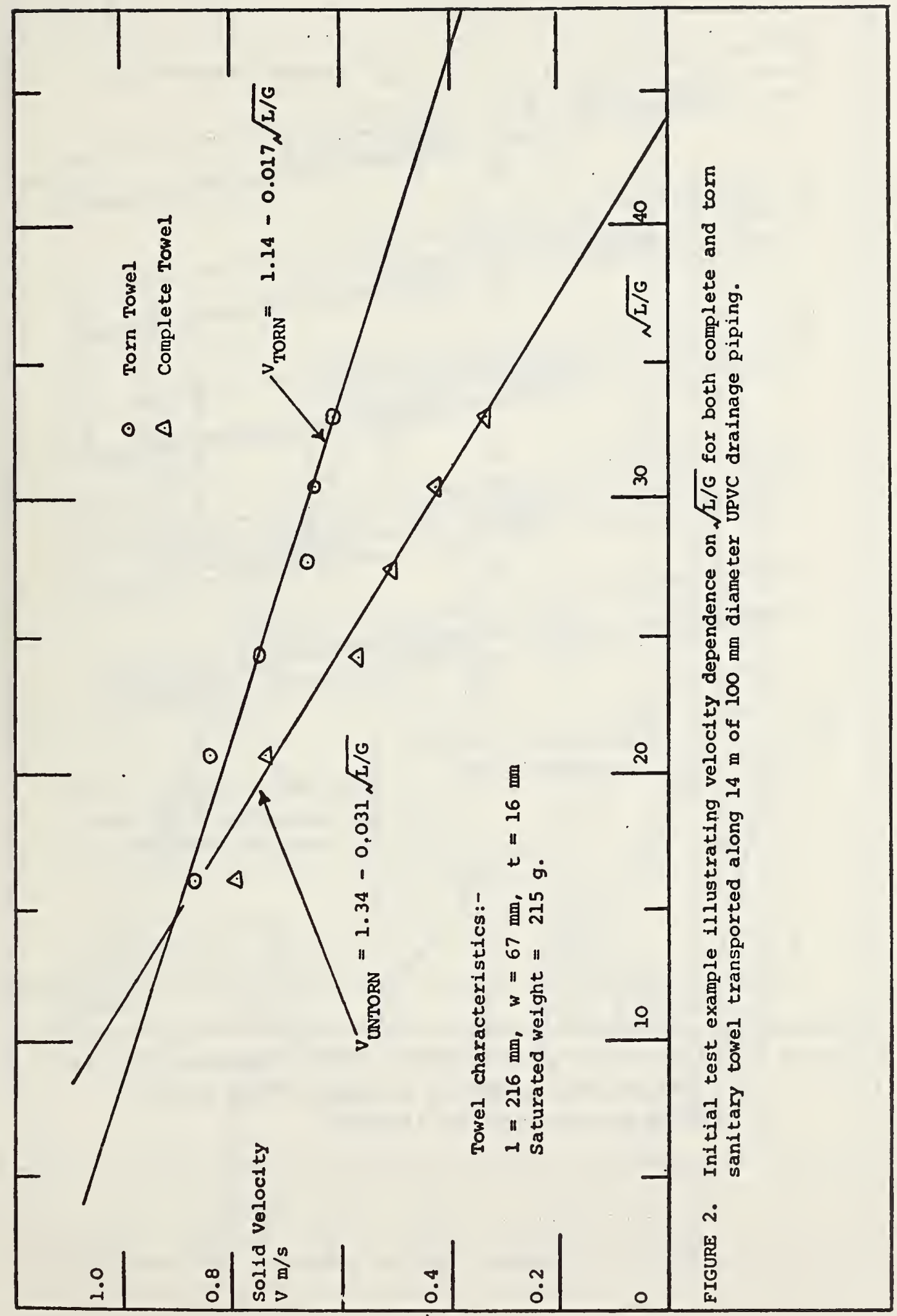




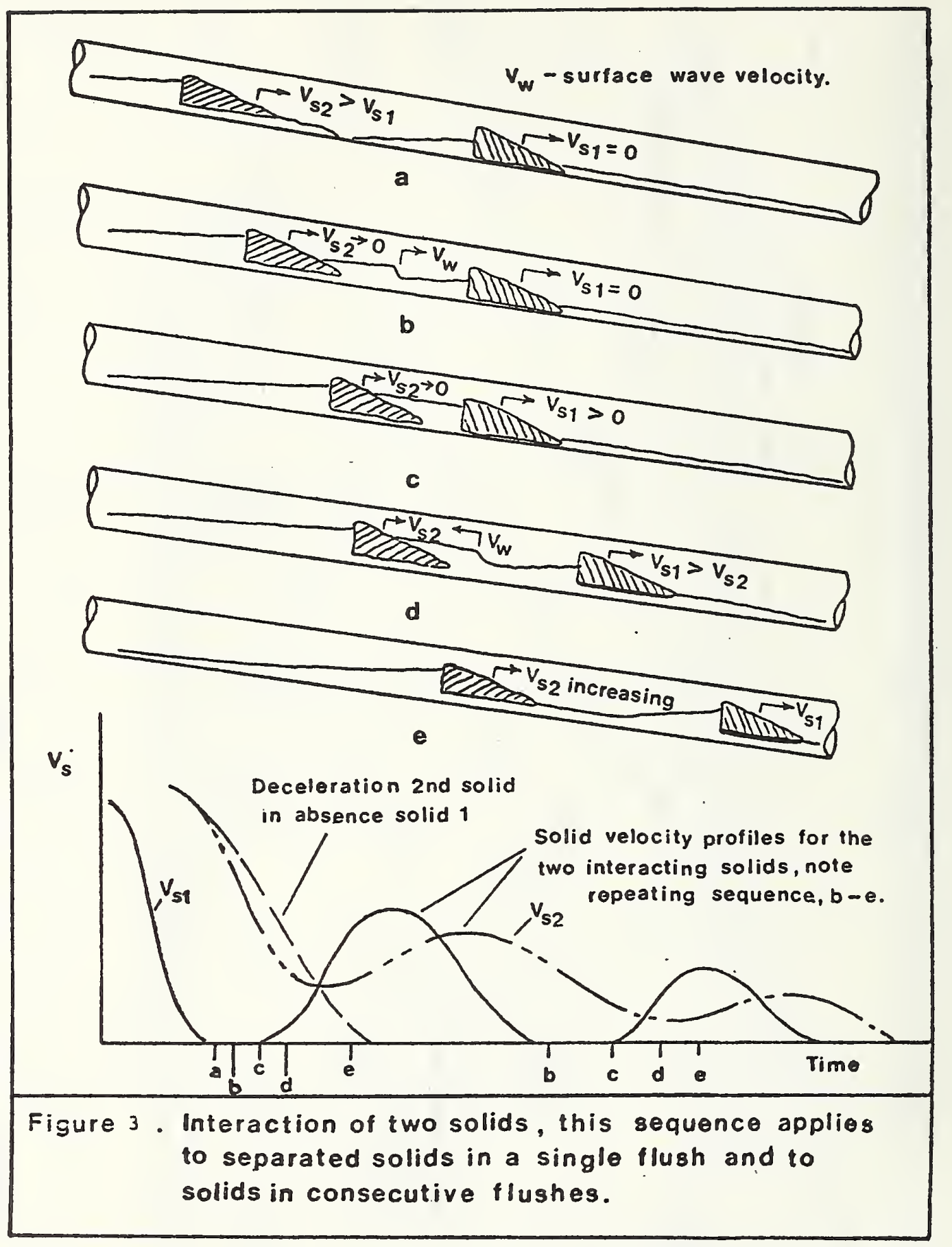




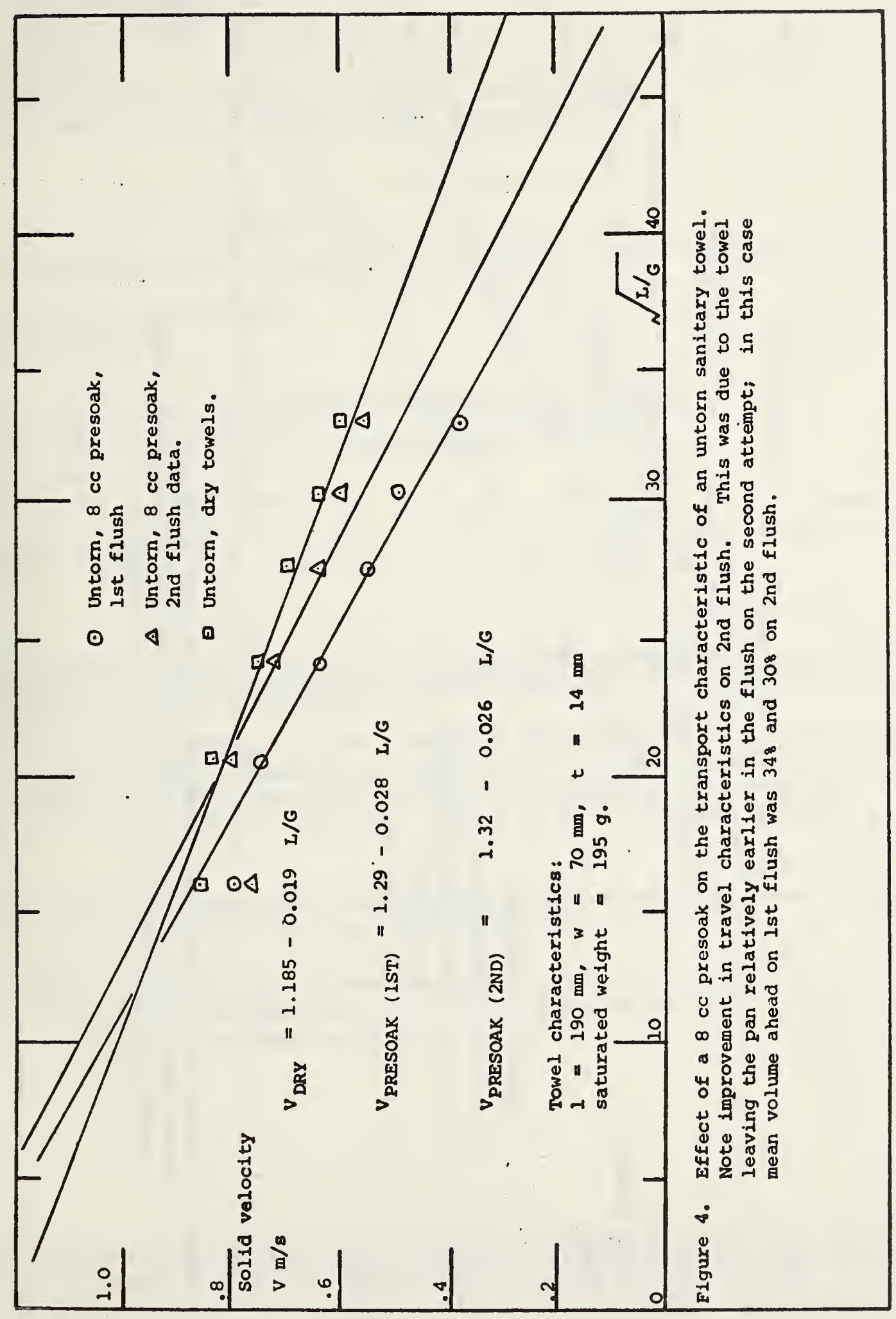




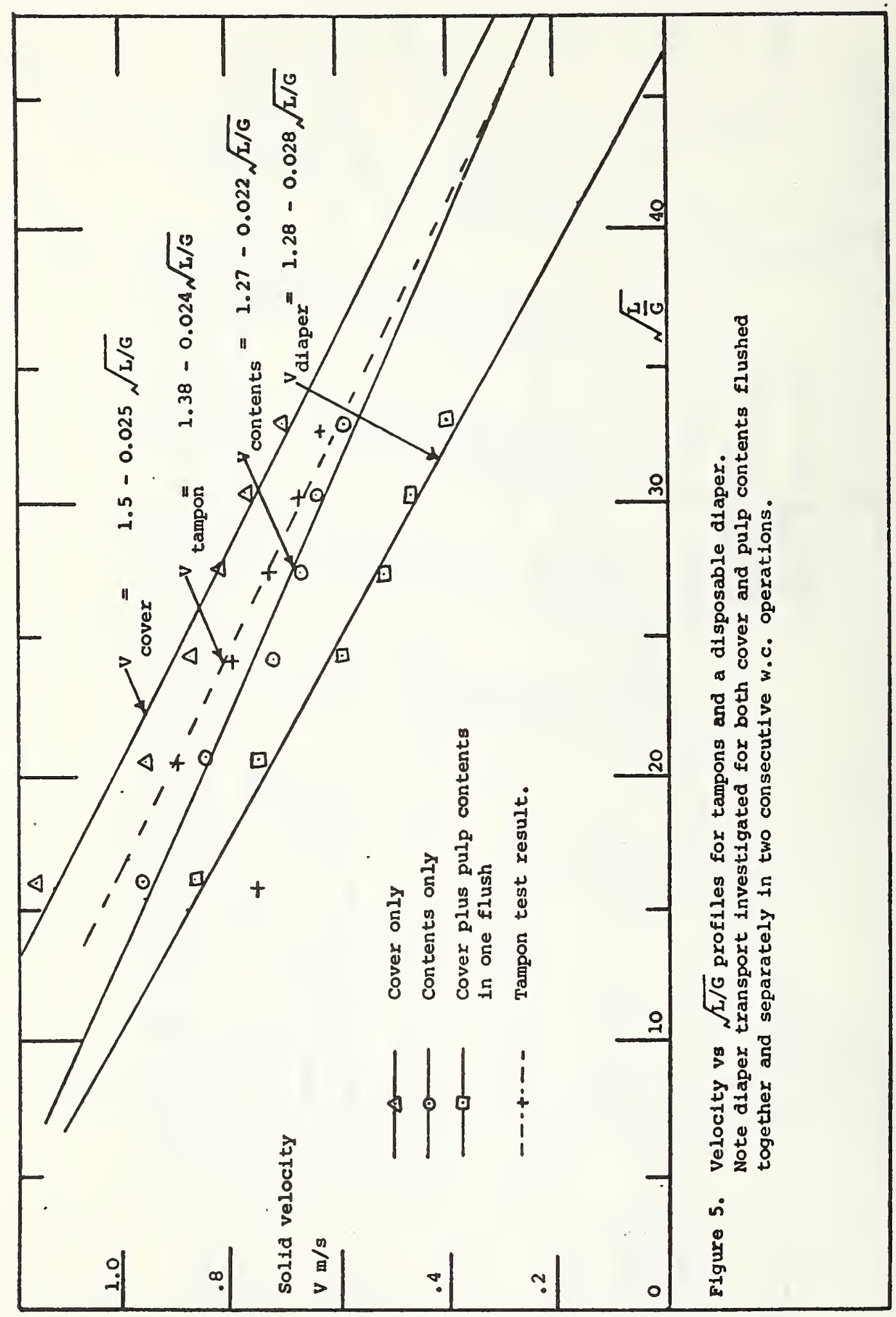


1. PUBLICATION OR REPORT NO.

NBSIR 81-2307
2. Performing Organ. Report No

July 1981
BIBLIOGRAPHIC DATA

SHEET (See instructions)

4. TITLE AND SUBTITLE

DEPENDENCE OF MODEL WASTE SOLID TRANSPORT CHARACTERISTICS IN DRAINAGE SYSTEMS

ON SOLID GEOMETRY, MASS AND PIPE SYSTEM PARAMETERS

\section{5. $\operatorname{AUTHOR}(S)$}

John A. Swaffield

6. PERFORMING ORGANIZATION (If joint or other than NBS, see in structions)

7. Contract/Grant No.

NATIONAL BUREAU OF STANDARDS

DEPARTMENT OF COMMERCE

WASHINGTON, D.C. 20234

9. SPONSORING ORGANHZATION NAME AND COMPLETE ADDRESS (Street, CItY, Stote, Zif)

Department of Housing and Urban Development

4517 th Street, SW

Washington, D.C. 20410

10. SUPPLEMENTARY NOTES

$\square$ Document describes a computer program; SF-185, FIPS Software Summary, is attached.

11. ABSTRACT (A 200-word or less factual summary of most significant information. If document includes a significant bibliography or literature survey. mention it here)

Test results are presented for the transport characteristics of an extensive range of geometrically similar model solids in a $100 \mathrm{~mm}$ diameter UPVC drain pipe. Model solids were based on commercially available sanitary towels (napkins) discharged into the pipe system via a series of U.K. standard watercloset (w.c.) types.

Following a data fit analysis, relationships are presented linking solid transport characteristics to solid, pipe and w.c. parameters.

These relationships, linked to observation of installed hospital drainage systems in the U.K., will allow laboratory test methods to be utilized in predicting the effect of design changes on system performance.

12. KEY WORDS (Six to twelve entries; alphobetical order; capitalize only proper names; and separate key words by semicolons) building drainage; waste solid transportation; water conservation; W.C. efficiency

\section{AVAILABILITY}

\section{X] Unlimited}

For Official Distribution. Do Not Release to NTIS

$\checkmark$ Order From Superintendent of Documents, U.S. Government Printing Office, Washington, D.C. 20402.

[X] Order From National Technical Information Service (NTIS), Springfield, VA. 22161
14. NO. OF

PRINTED PAGES

44

15. Price

$\$ 6.50$ 


